\title{
Insulin therapy waste produced in the households of people with diabetes monitored in Primary Care
}

\author{
Resíduos de insulinoterapia produzidos no domicílio de diabéticos acompanhados na Atenção Primária
}

Los residuos de la terapia con insulina en las viviendas de personas con diabetes asistidas en atención primaria

\section{Gilmara Holanda da Cunha', Raiza Verônica Almeida Barbosa', Marina Soares Monteiro Fontenele', Maria Amanda Correia Lima', Katia Barbosa Franco', Francisco Vagnaldo Fechine" \\ ' Universidade Federal do Ceará, Nursing Department. Fortaleza, Ceará, Brazil. \\ "Universidade Federal do Ceará, Center for Research and Development of Medicines. Fortaleza, Ceará, Brazil.}

\section{How to cite this article:}

Cunha GH, Barbosa RVA, Fontenele MSM, Lima MAC, Franco KB, Fechine FV. Insulin therapy waste produced in the households of people with diabetes monitored in Primary Care.

Rev Bras Enferm [Internet]. 2017;70(3):618-25. DOI: http://dx.doi.org/10.1590/0034-7167-2016-0406

\author{
Submission: 07-12-2016 Approval: 01-18-2017
}

\begin{abstract}
Objective: To analyze the insulin therapy waste disposal produced in the households of people with diabetes mellitus (DM). Method: Cross-sectional study with 105 Primary Care patients. Socio-demographic and clinical variables and insulin therapy practice were analyzed through the absolute and relative frequencies, Fisher's exact test and prevalence ratio (PR). Results: The association between types of insulin $(60.0 \%)$, administered with a disposable syringe attached to a needle $(80.9 \%)$, and a high percentage of reuse and disposal in normal household waste $(57.1 \%)$ stood out. The professionals who most frequently provided guidance to people with diabetes were the nurses. Patients who had received instructions about disposal were 21 times more likely to dispose of waste properly than those who had not (PR 21.5; $\mathrm{P}<0.0001)$. Age, gender, skin color, education, marital status, occupational status and type of DM did not interfere in the disposal $(P>0.05)$. Conclusion: People with diabetes served in Primary Health Care require guidance and material resources to carry out the appropriate disposal of insulin therapy waste. Descriptors: Diabetes Mellitus; Insulin; Disposal of Health Services Residues; Nursing; Health Promotion.
\end{abstract}

RESUMO

Objetivo: Analisar o descarte de resíduos da insulinoterapia produzidos no domicílio de pessoas com diabetes mellitus (DM). Método: Estudo transversal com amostra de 105 pacientes da Atenção Primária. Variáveis sociodemográficas, clínicas e prática de insulinoterapia foram analisadas por meio das frequências absoluta e relativa, teste exato de Fisher e razão de prevalência (RP). Resultados: Destacou-se associação entre insulinas $(60,0 \%)$, administradas com seringa descartável acoplada à agulha $(80,9 \%)$, alto percentual de reutilização e descarte no lixo doméstico comum $(57,1 \%)$. Os profissionais que mais orientaram os diabéticos foram os enfermeiros. Pacientes orientados sobre descarte tiveram 21 vezes mais chances de descartarem resíduos adequadamente que os não orientados (RP 21,5; P < 0,0001). Idade, sexo, cor da pele, escolaridade, estado civil, situação ocupacional e tipo de DM não interferiram no descarte $(P>0,05)$. Conclusão: Diabéticos atendidos na Atenção Primária necessitam de orientações e recursos materiais para realizarem descarte adequado dos resíduos da insulinoterapia.

Descritores: Diabetes Mellitus; Insulina; Eliminação de Resíduos de Serviços de Saúde; Enfermagem; Promoção da Saúde.

\section{RESUMEN}

Objetivo: Analizar la eliminación de los residuos de la terapia con insulina en las viviendas de personas con diabetes mellitus (DM). Método: Estudio transversal, del cual participaron 105 pacientes asistidos en atención primaria. Se analizaron las variables sociodemográficas, clínicas y la administración de la terapia con insulina a través de las frecuencias absoluta y relativa, la prueba exacta de Fisher y la razón de prevalencias (RP). Resultados: Se destacaron la asociación entre insulinas $(60,0 \%)$ aplicadas con jeringuillas desechables pegadas a la aguja $(80,9 \%)$, su elevado porcentaje de reutilización y su eliminación en la basura doméstica común $(57,1 \%)$. Los enfermeros fueron los profesionales que más orientaron a los pacientes con diabetes. Los pacientes orientados presentaron más de 21 posibilidades de eliminar correctamente los residuos que los que no recibieron orientación (RP 21,5; 
$\mathrm{p}<0$,0001). La edad, sexo, etnia, nivel de instrucción, estado civil, situación laboral y tipo de DM no influyeron en los resultados para la eliminación de estos residuos $(p>0,05)$. Conclusión: Las personas con diabetes asistidas en atención primaria carecen de recomendaciones y recursos materiales que les informen la correcta eliminación de los residuos de la terapia con insulina.

Descriptores: Diabetes Mellitus; Insulina; Eliminación de Residuos de Servicios de Salud; Enfermería; Promoción de la Salud.

CORRESPONDING AUTHOR

Gilmara Holanda da Cunha

E-mail: gilmaraholandaufc@yahoo.com.br

\section{INTRODUCTION}

Diabetes Mellitus (DM) is a group of metabolic diseases characterized by hyperglycemia and disturbances in the metabolism of carbohydrates, proteins and fats, being related to organ dysfunctions and failure, especially the eyes, kidneys, nerves, brain, heart and blood vessels. It results from defects in insulin secretion or in its malfunctioning, from the destruction of the beta cells of the pancreas, from insulin resistance, among others ${ }^{(1)}$.

DM's importance has been increasing due to its growing prevalence and association with dyslipidemias, systemic arterial hypertension and endothelial dysfunction. It is asymptomatic in most cases and, sometimes, diagnosis is made from chronic complications ${ }^{(1)}$. Treatment is conducted via pharmacological and non-pharmacological measures ${ }^{(2)}$. The goal is to control blood glucose levels, so that the patient stays symptom-free and does not have acute and chronic complications, promoting quality of life and reducing mortality ${ }^{(3-5)}$.

In this context, insulin therapy is one of the most important treatments for people with DM and also the one which requires the most care. In addition to requiring attention in what concerns the administration procedures, insulin therapy is a waste producer, which includes needles, lancets, cotton, syringes and reagent strips ${ }^{(5-6)}$. Since people with diabetes can make several applications of insulin a day and verify capillary blood glucose, they must be instructed on the handling and disposal of waste. As it is an invasive procedure, independently of the location, there will be risks associated with health care ${ }^{(7)}$.

Waste from services related to the care of human and animal health, including household waste, are characterized as Health Services Residues $(\mathrm{RSSs})^{(8)}$. This type of waste needs special treatment in all phases of management, since it is composed of chemical, physical and biological elements, harmful to the environment and to people ${ }^{(9)}$. RSSs are classified into groups: A (potentially infective); B (chemical); C (radioactive); $\mathrm{D}$ (common) and $\mathrm{E}$ (sharp). Waste management should follow the steps of segregation, packaging, identification, internal transport, temporary storage, treatment, external storage, collection and external transport and final disposal(8). Waste from insulin therapy generated in home care, represented by groups $\mathrm{A}, \mathrm{B}$ and $\mathrm{E}$, must be packaged and collected by professionals and forwarded to the reference health institutions ${ }^{(7)}$.

Taking all of this into consideration, nurses have a vital role in the instructing of diabetic patients, and it is noted that the handling of insulin therapy waste is seldom addressed in the literature and in health units. Thus, this essay had as objective analyzing the fate of waste generated during the practice of insulin therapy in the homes of people with DM monitored in Primary Health Care, with emphasis on the demographic and clinical characterization of patients, in addition to the disposal of material. This research can assist in the implementing of health education activities directed towards the patients' context and resources.

\section{METHOD}

\section{Ethical aspects}

The project was submitted to the Research Ethics Committee of the Federal University of Ceará (UFC), according to Resolution No. 466/2012 of the National Health Council(10) and approved in 8/14/2014. All participants signed the Informed Consent Form (ICF).

\section{Study design, location, and period}

This is a cross-sectional, descriptive and quantitative study developed between September 2014 and September 2015, in a Primary Health Care Unit (UAPS) in Fortaleza, Ceará, Brazil. UAPS are part of the Primary Care network of the Brazilian Unified Health System (SUS), serving an appointed area of three neighborhoods, accounting for 24,414 people registered by the Community Health Agents (ACS).

\section{Sample, inclusion and exclusion criteria}

The sample was scaled to estimate the prevalence of patients on insulin therapy who conformed to the appropriate practices of this procedure, with $95 \%$ confidence that the error of the estimate would not exceed $5 \%$. It was considered that such prevalence is unknown in the population, being stipulated in 50\% (suspected prevalence) as it provides a bigger sample size; and that there was in the period a total of 143 patients on insulin therapy monitored in Primary Care, in accordance with the System of Registration and Monitoring of Hypertensive and Diabetic Patients (Hiperdia).

For this, the following expression was applied:

$$
n=\begin{gathered}
z^{2} \cdot p \cdot(1-p) \cdot N \\
\varepsilon^{2} \cdot(N-1)+z^{2} \cdot p \cdot(1-p)
\end{gathered}
$$

In this formula, $z$ is equal to the value of the $z$ statistic (1.96) for the adopted degree of confidence $(95 \%)$ and $p, N$ and $\varepsilon$ correspond to the assumed prevalence $(0.50)$, to the population (143) and to the tolerable error (0.05), respectively. Thus, a sample of 105 patients was calculated.

The inclusion criteria adopted were: patients with DM type 1 or 2, registered in the Hiperdia of the health facility where the study was conducted and who had been on insulin therapy for at least six months. Exclusion criteria were: pregnancy, mental illness, being homeless or living in a shelter home and any other condition that interfered with the answers to the questions prepared by the researcher. 


\section{Study protocol}

For the selection of the participants, convenience sampling was used. As they attended the service for consultations, they were invited to participate in the study. Data collection took place in a private environment through interviews with an average duration of 40 minutes, using two instruments: Sociodemographic and Clinical Characterization Form for Diabetic Patients and Form for Analysis of the Insulin Therapy Waste Produced at the Household of Diabetic Patients. Before starting the study, these forms were submitted to the pre-test with patients who were not part of the sample, in addition to being discussed at the health unit itself.

\section{Analysis of results and statistics}

In the descriptive statistics, the absolute and relative frequencies were determined. The association between independent variables was evaluated through Fisher's exact test. The strength of such association was verified by determining the ratio of prevalence and considering a 95\% confidence interval. The prevalence ratio was obtained through the division between the prevalence of correct disposal among the patients who were instructed on it and the prevalence of correct disposal among the patients who were not. Significance level was settled at $0.05(5 \%)$, considering a value of $p<$ 0.05 as statistically significant. The Statistical Package for the Social Sciences ${ }^{\circledR}$ software 19.0 version was used for the statistical procedures.

\section{RESULTS}

Most diabetic patients were older than 50 (80.9\%), female $(66.7 \%)$, had skin color self-reported as mixed (68.6\%), were married or in a common-law marriage (55.2\%), pensioners $(54.3 \%), 20.9 \%$ of the sample being illiterate, which may interfere negatively in the treatment. Type 2 diabetic patients prevailed $(87.6 \%)$, who had been diagnosed more than 10 years ago $(66.7 \%)$. Only $55.2 \%$ did not have comorbidities associated with DM, but there was a high frequency of retinopathy $(31.4 \%)$. It should be noted that, for this variable, the total percentage is greater than $100 \%$ because some patients had more than one comorbidity. See Table 1.

The average number of people at the household and of the family monthly income were, respectively, 3.6 people and $\mathrm{R} \$ 1,961.85$. Also, 66 patients had never smoked, 34 stopped smoking after the DM type 2 diagnosis and five were still smoking after DM. In what concerns alcoholism, 68 had never used alcohol, 21 stopped using it after the DM diagnosis and 16 still used it daily.

Most of the patients $(60.0 \%)$ used an association between regular insulin and Neutral Protamine Hagedorn (NPH), with management through a disposable syringe attached to the needle $(80.9 \%)$. Capillary blood glucose verifying was held at the household by $92.4 \%$ of the patients, from once a day $(18.1 \%)$ to once a week $(20 \%)$. The use of insulin three times a day $(28.6 \%)$, with the same syringe $(79 \%)$ and needle $(93.3 \%)$ was common, a high percentage of reuse of syringes and needles having been noted. See Table 2 .
Table 1 - Demographic and clinical characterization of diabetic patients monitored in a Primary Health Care Unit ( $=105)$, Fortaleza, Ceará, Brazil, September 2014 to September 2015

\section{Clinical and sociodemographic variables}

n $\quad \%$

$\begin{array}{lcc}\text { Age group (years) } & & \\ \leq 29 & 7 & 6.7 \\ 30-39 & 3 & 2.9 \\ 40-49 & 10 & 9.5 \\ >50 & 85 & 80.9 \\ \text { Gender } & & \\ \quad \text { Male } & 35 & 33.3 \\ \text { Female } & 70 & 66.7 \\ \text { Self-reported skin color } & & \\ \quad \text { White } & & \\ \text { Mixed } & 33 & 31.4 \\ \end{array}$

Education level (years)

Illiterate

$<8$ years

$\geq 8$ years

$22 \quad 20.9$

$39 \quad 37.1$

$44 \quad 42.0$

Marital status

Single

Married/Common-law marriage

Widowed/divorced/separated

2120.0

$58 \quad 55.2$

$26 \quad 24.8$

Position of the person with diabetes in the family

Father

$26 \quad 24.8$

Mother

Son

Occupational situation

Employee

20.9

Unemployed

Retiree

Housewife

Type of diabetes mellitus

Diabetes mellitus type 1

$13 \quad 12.4$

Diabetes mellitus type 2

$92 \quad 87.6$

Time of diagnosis (in years)

$0-9$

$35 \quad 33.3$

$>10$

$\begin{array}{ll}70 & 66.7\end{array}$

Comorbidities associated with diabetes

Does not have comorbidities

Diabetic foot

15.3

Retinopathy

31.4

Nephropathy

6.7

Cardiovascular diseases

Approximately half of the patients received guidance during the consultations in the health service about the disposal of the material used in capillary blood glucose and insulin administration $(51 \%)$. In $90 \%$ of cases, they received it from the nurses at the service, while others stated that they received it from doctors 
Table 2 - Characteristics of insulin therapy in diabetic patients monitored in a Primary Health Care Unit (N = 105), Fortaleza, Ceará, Brazil, September 2014 to September 2015

Characteristics of insulin therapy practice
Insulin type
Neutral Protamine Hagedorn (NPH)
Regular and Neutral Protamine Hagedorn (NPH)
Others

n $\%$

Amount of needles and syringes used per month

Does not use a syringe

$$
\begin{aligned}
& 1-10 \\
& 11-20 \\
& 21-30 \\
& >30
\end{aligned}
$$

Amount of pens used per month

$$
\begin{aligned}
& \text { Does not use a pen } \\
& 1-5 \\
& 5-10
\end{aligned}
$$

Syringe type used in the application of insulin

Does not use a syringe due to using a pen instead

Disposable syringe attached to the needle

Disposable syringe not attached to the needle

Capillary blood glucose verifying at one's own house

Yes

No

Frequency of capillary blood glucose verifying

\section{Not often}

Once a day

Twice a day

$19 \quad 18.1$

$\begin{array}{ll}16 & 15.2\end{array}$

Thrice a day

$17 \quad 16.2$

More than three times a day

Once per week

Two times a week

Three times a week

More than three times a week

$11 \quad 10.5$

2120.0

$\begin{array}{ll}6 & 5.7\end{array}$

$\begin{array}{ll}7 & 6.7\end{array}$

$4 \quad 3.8$

Number of insulin uses per day

1

2

3

4

$15 \quad 14.2$

$36 \quad 34.3$

$30 \quad 28.6$

$24 \quad 22.9$

Re-use of disposable syringe

Does not use a syringe, but a pen

Yes

$\begin{array}{ll}16 & 15.3\end{array}$

$83 \quad 79.0$

No

$\begin{array}{ll}6 & 5.7\end{array}$

Re-use of disposable needle

Yes

No $\begin{array}{ll}98 & 93.3\end{array}$

$\begin{array}{ll}7 & 6.7\end{array}$
(10\%). However, $57.1 \%$ of respondents discarded syringes, needles, lancets, insulin vials, cotton, reagent tapes and pens in normal household waste. In most cases (63.8\%), the patients did not have a suitable container to discard the materials, which were neglected as household waste. In cases where a suitable container was used, when it was full, it was also neglected as household waste $(22.9 \%)$. Three patients reported accidents involving sharp insulin therapy materials with residents of the household, which took place at the time of disposal during the removal of the waste from the location. See Table 3.

Associations were made between the following variables: guidance on the disposal, age, gender, skin color, education, marital status, occupational status, type of diabetes and time of diagnosis with correct or incorrect destination given to the waste. Fisher's exact test and prevalence ratio (PR) with a $95 \%$ confidence interval $(\mathrm{Cl} 95 \%)$ were used. There was

Table 3 - Destination of insulin therapy waste produced by diabetic patients monitored in a Primary Health Care Unit $(\mathrm{N}=105)$, Fortaleza, Ceará, Brazil, September 2014 to September 2015

\section{Destination of insulin therapy waste n $\%$}

Guidance on disposal of waste from glucose/insulin administration

$$
\begin{array}{lll}
\text { Yes } & 51 & 48.6 \\
\text { No } & 54 & 51.4
\end{array}
$$

Disposal of syringes, needles and lancets after use $\begin{array}{lll}\text { Does not use a syringe } & 16 & 15.3\end{array}$ $\begin{array}{lll}\text { In a hard and durable container } & 6 & 5.7\end{array}$ $\begin{array}{lll}\text { Polyethylene terephthalate bottle (PET) } & 17 & 16.2\end{array}$ $\begin{array}{lll}\text { Household waste } & 60 & 57.1\end{array}$ Others

Disposal of reagent strips after use

Does not use them

In a hard and durable container

$4 \quad 3.8$

Polyethylene terephthalate bottle (PET)

$4 \quad 3.8$

Household waste

Others

Disposal of empty insulin bottle after use

Does not use them

Adequate container for sharp materials

In a hard and durable container

Polyethylene terephthalate bottle (PET)

Household waste

Others

Disposal of cotton after use

Does not use them

In a hard and durable container

Polyethylene terephthalate bottle (PET)

0.9

Household waste

$3 \quad 2.9$

$8 \quad 7.6$

$91 \quad 86.7$

Others 


\section{Destination of insulin therapy waste}

n $\%$

Disposal of pens after use

Does not use a pen

Polyethylene terephthalate bottle (PET)

Household waste

Others

Destination of the container for disposal when it is full

Material delivered in the health unit

Material placed for garbage collection, but

separated from household waste

Material does not have its own container and is treated like common waste

Accident involving sharp materials with the household residents

Yes

No significance only for guidance on the disposal, because the proportion of people who did it properly was significantly higher among those who had been previously instructed on it, when compared with those who had not.

Therefore, patients who were instructed on it are 21 times more likely to properly discard the waste than those who were not. These findings demonstrate the importance of health education in the treatment of people with chronic conditions, such as DM. For the variables age, gender, skin color, education, marital status, occupational status and type of diabetes there was no statistical significance ( $p$ value $>0.05$ ). Table 4 shows this information.

\section{DISCUSSION}

Most patients were more than 50 years old, which can be justified by the fact many of them have type 2 diabetes. DM type 2 usually affects older individuals, being diagnosed in adults with a family history of DM and excess weight, representing a typical disease of the $40+$ age group in Brazil(11).

Table 4 - Evaluation of the effect of prior guidance on the correct disposal of waste from insulin therapy by diabetic patients monitored in a Primary Health Care Unit (N = 105), Fortaleza, Ceará, Brazil, September 2014 to September 2015

\begin{tabular}{|c|c|c|c|c|c|c|}
\hline \multirow{3}{*}{ Disposal of the waste } & \multicolumn{4}{|c|}{ Guidance on the disposal } & \multirow{3}{*}{$\begin{array}{l}\text { Prevalence Ratio }(95 \% \\
\text { confidence interval) }\end{array}$} & \multirow{3}{*}{$\begin{array}{c}p \text { value } \\
\text { (Fisher's Test) }\end{array}$} \\
\hline & \multicolumn{2}{|c|}{ Yes } & \multicolumn{2}{|c|}{ No } & & \\
\hline & $\mathbf{n}$ & $\%$ & $\mathbf{n}$ & $\%$ & & \\
\hline \multicolumn{7}{|l|}{ Syringes and needles } \\
\hline Correct & 22 & 48.8 & 1 & 2.2 & \multirow{2}{*}{$\begin{array}{c}21.51 \\
(3.03-152.86)\end{array}$} & \multirow[t]{2}{*}{$<0.0001$} \\
\hline Incorrect & 23 & 51.1 & 43 & 97.7 & & \\
\hline \multicolumn{7}{|l|}{ Lancets } \\
\hline Correct & 21 & 42.0 & 0 & 0.0 & \multirow[t]{2}{*}{-} & \multirow[t]{2}{*}{$<0.0001$} \\
\hline Incorrect & 29 & 58.0 & 51 & 100.0 & & \\
\hline \multicolumn{7}{|l|}{ Reagent tapes } \\
\hline Correct & 21 & 42.0 & 0 & 0.0 & \multirow[t]{2}{*}{-} & \multirow[t]{2}{*}{$<0.0001$} \\
\hline Incorrect & 29 & 58.0 & 51 & 100.0 & & \\
\hline \multicolumn{7}{|l|}{ Insulin vials } \\
\hline Correct & 12 & 26.6 & 1 & 2.2 & \multirow{2}{*}{$\begin{array}{c}11.73 \\
(1.59-86.50)\end{array}$} & \multirow[t]{2}{*}{0.0017} \\
\hline Incorrect & 33 & 73.3 & 43 & 97.7 & & \\
\hline \multicolumn{7}{|l|}{ Cotton } \\
\hline Correct & 11 & 21.5 & 0 & 0.0 & \multirow[t]{2}{*}{-} & \multirow[t]{2}{*}{0.0002} \\
\hline Incorrect & 40 & 78.4 & 53 & 100.0 & & \\
\hline \multicolumn{7}{|l|}{ Pens } \\
\hline Correct & 2 & 28.5 & 0 & 0.0 & \multirow[t]{2}{*}{-} & \multirow[t]{2}{*}{0.1373} \\
\hline Incorrect & 5 & 71.4 & 11 & 100.0 & & \\
\hline \multicolumn{7}{|l|}{ Disposal container } \\
\hline Correct & 14 & 27.4 & 0 & 0.0 & \multirow[t]{2}{*}{-} & \multirow[t]{2}{*}{$<0.0001$} \\
\hline Incorrect & 37 & 72.5 & 54 & 100.0 & & \\
\hline \multicolumn{7}{|c|}{ Accidents with the material } \\
\hline Yes & 1 & 1.9 & 2 & 3.7 & & \multirow[t]{2}{*}{$<0.0001$} \\
\hline No & 50 & 98.0 & 52 & 96.3 & $(0.05-5.67)$ & \\
\hline
\end{tabular}


Despite the new treatments for DM, including sophisticated devices and continuous insulin infusion pumps, appropriate metabolic control is still a challenge for the professionals that monitor these patients. The daily care to diabetic patients is performed by the own patient or his/her family, requiring continuous monitoring for the promotion of self-care ${ }^{(2,12-13)}$. These aspects are relevant, especially in what concerns the elderly, because many already have disabilities, do not change their life habits easily, and some are unable to fully perform self-care.Also, knowing the position occupied by the person in the family is important to get to know the members who will be able to assist him/her in this process.

There were more females than males in the sample analyzed, highlighting the fact that, in Brazil, there are more women than men with diabetes, which shows that this is a particularly vulnerable group that requires special attention ${ }^{(1-2)}$. The participants who self-reported being of mixed raced predominated. In this regard, there are no studies showing that ethnicity influences on DM. However, for systemic arterial hypertension, it is said that individuals with dark skin are more likely to develop hypertension, although there are no studies proving the effect of miscegenation on hypertension ${ }^{(14)}$.

Many diabetic patients had a low education level and some were also illiterate. This finding may negatively influence treatment, because it interferes with the understanding of therapy, and as consequence researches show a lower school level as being associated with the worst levels of adherence to pharmacological and non-pharmacological measures ${ }^{(1-4)}$.Given this, the importance of functional health literacy, which is the ability of the individual to follow health guidelines, regardless of his/her educational level, becomes evident, because a person can have a good level of formal instruction, but not follow the health guidelines satisfactorily ${ }^{(15)}$.

Those retired, married or in a common-law marriage prevailed in the sample. The fact of being retired facilitates the practice of insulin therapy. Patients who work must carry insulin and other necessary equipment around. The support of family members facilitates the treatment for DM, especially when the patient has physical or mental incapacities ${ }^{(12)}$. In relation to the use of smoke and alcohol, although some patients reported having never used either, the number of those who quit was quite high for both cases. The use of alcohol and smoke in patients with DM can lead to comorbidities or exacerbate them when they already exist $^{(1)}$. A diagnosis of more than 10 years was reported by many patients, the most common aggravating factor being retinopathy. The preservation of vision in diabetic patients is considered to be crucial; thus, interventions to improve glycemic control through the early and intensive treatment of DM reduce the rates of severe retinopathy and preserve visual acuity ${ }^{(16)}$.

Other studies have also reported that most patients on insulin therapy are decompensated type 2 diabetic ${ }^{(1,17)}$, showing that self care in the administration of medications, blood glucose monitoring and the correct disposal of insulin therapy waste are essential for maintaining the quality of life of these people ${ }^{(3)}$. It is important to remember that uncontrolled DM can cause, in the long term, dysfunction and failure of various organs, especially kidneys, eyes, nerves, heart and blood vessels ${ }^{(2)}$.
Type 2 DM requires non-pharmacological treatment, usually supplemented with oral anti-diabetic treatment and, eventually, one or two doses of basal insulin depending on the evolution of the disease. Cases that require more complex forms of treatment, such as those with fractionated doses and insulin mixtures (two to four injections a day), are generally monitored by specialized care. These medical indications have the goal of keeping glycemic control in excellent levels to prevent comorbidities ${ }^{(1-2)}$.

Among the waste generated by patients with DM in their homes, the occurrence of pens and insulin vials, needles, syringes, lancets, cotton and reagent tapes was noted. It is estimated that more than 7,500,000 syringes are used in households per year, with diabetic patients being the majority of users, and this number does not include the number of lancets used by the 25 million people with $\mathrm{DM}^{(18-19)}$.

Given this, it has been suggested that syringes and disposable needles may be reused by the user of insulin, up to eight times, as long as the needle hasn't been contaminated, or caused discomfort during administration.It has also been suggested that syringes and needles may be kept at room temperature, and, after use, that the syringe should be covered, cleaning the needle with alcohol not being recommended ${ }^{(1)}$. However, the current recommendation advocates the use of syringes and needles only once ${ }^{(13)}$; however, in this research, it was found that many individuals did not comply with this.

Many insulin-dependent diabetic patients are not instructed on safe ways of disposing of sharp objects, leading to the incorrect disposal of needles. Strategies of health education about the disposal of these materials must integrate the counseling on the disease, assigning to the multidisciplinary team the responsibility of educating and reinforcing the information about the correct methods of waste disposal ${ }^{(20)}$.

Although plastic water or soft drink bottles are widely used, named polyethylene terephthalate bottles (PET), they are not recommended for discarding material because of their frailty. The disposal of syringes and of the needles attached to them should be performed in a container suitable for sharp materials, provided by the health unit, or in a hard durable container such as an empty bottle of fabric softener. When the container is full, the material must be delivered to the health unit, so that it can carry out the appropriate disposal ${ }^{(1)}$. In this research, the number of people who have received guidance on the disposal of the material used in the testing of glucose and in insulin application was almost equivalent to the amount of people who have not received it, making the groups homogeneous in relation to this aspect.

Health care waste must be segregated at the time and place of their generation, according to their physical, chemical characteristics and biological risks involved. They must be packed in containers that prevent leaks and resist puncture and rupture actions, and subsequently transported to the location intended for temporary or external storage, so they can then be collected. Patients should be advised to dispose of sharp objects in durable containers and to return them safely to the health institutions for their correct disposal, and should also be educated about the health risks associated with the needles used ${ }^{(20)}$.

In general, diabetic patients treat insulin therapy waste as household waste, common trash cans being the most commonly 
used for disposal. Even when they put the waste in PET bottles, it ends up being thrown in common trash cans at the moment of disposal. They should be instructed that it is not enough to just separate the sharp materials; it is necessary to analyze the possible treatment and final destination, to minimize the impact on the environment ${ }^{(17-20)}$.

Few patients carried out the proper disposal of sharp materials, because many did not use appropriate containers and did not deliver the material in the health unit. Those who made use of pens also threw them in common trash cans. Another research also shows that diabetic patients generally dispose of insulin therapy devices in the household waste; in contrast, those who have higher education dispose of them more properly ${ }^{(19)}$. The likelihood of accidents involving this material should be considered, as one of the types of waste generated in insulin therapy are sharp objects. When health care waste is disposed of incorrectly it can cause accidents among family members, the community and garbage collectors. This fact can lead to the occurrence of outbreaks of infections, such as by the human immunodeficiency virus (HIV), hepatitis $B$ and $C^{(3)}$. However, it was noted that, despite the incorrect disposal held by most participants, there were few accidents at the household involving the sharp materials.

In the association between the guidance on disposal, age, gender, skin color, education, marital status, occupational status, type of diabetes and time of diagnosis variables with the correct or incorrect destination of waste, there was association for the variable "guidance on disposal". The proportion of people who disposed of waste correctly was significantly higher among those who had previously been instructed on it, when compared to those who had not, those who had been instructed being 21 more likely to properly carry out the disposal.

The disposal of sharp objects in household waste has implications for the transmission of diseases ${ }^{(19)}$. Health education contributes so that individuals with chronic conditions live a better life, strengthen their perception on health risks and develop skills for self-care ${ }^{(1)}$. The professionals who most frequently provided guidance to people with diabetes were the nurses. A survey shows that one of the barriers faced by patients includes the lack of guidance by the multidisciplinary health team on the disposal, there being misperceptions: that the information about the disposal of sharp objects must be intended for users of illicit drugs; and that health waste disposal services in the community exposes their disease $\mathrm{e}^{(3)}$.

The lack of guidance associated with misperceptions on the part of patients can contribute to the improper disposal of insulin therapy waste. It becomes clear that proper orientation, focused on self-care and on the empowerment of diabetic patients, has positive aspects for the handling of insulin therapy and for adequate waste disposal ${ }^{(15)}$.

\section{Study limitations}

One factor that limited the development of the study was the change in the management model of the municipality, because the care to diabetic patients no longer has specific schedules in the Primary Health Care Units (UAPS), hindering the recruitment of participants for the study, as well as interfering in the performing of group health education strategies. Another limitation of the study is its cross-sectional nature, new researches that are able to monitor these patients for longer periods of time being suggested.

\section{Contributions to the fields of nursing, health and public policies}

The findings of this study show that proper health guidance impacts significantly on the treatment of patients. Therefore, the conducting of more health education strategies in Primary Health Care Units, aimed at the empowerment and self-care of diabetic patients and at the managing of insulin therapy waste by them becomes necessary. It should be noted that the family and the social support network have important role in this process, especially when it comes to the elderly. Thus, this research may aid in the assessing and implementing of strategies involving public health and the environment.

\section{CONCLUSION}

There was prevalence of type 2 diabetic patients, with more than 10 years of diagnosis, female, elderly, of mixed race, married, retired and with a low education level. Retinopathy was the most common comorbidity. The use of regular and NPH insulin administered through a disposable syringe attached to a needle stood out, with a high percentage of reuse. Only about half of the patients received guidance on the disposal of insulin therapy waste, usually provided by nurses. Even so, many disposed of the material in inappropriate containers and in common household waste. Age, gender, skin color, education, marital status, occupational status, type of diabetes and time of diagnosis did not influence on the destination of the waste, but the guidance on the disposal interfered positively so that it occurred correctly.

In light of the above, it is noted that there is a need for researches to address the self-care of diabetic patients, aiming at health education practices directed towards the existing contexts, considering their level of education and socioeconomic condition. Furthermore, studies which are able to evaluate the educational strategies and their impact on the quality of life of patients with chronic health conditions are essential.

\section{REFERENCES}

1. Brasil. Ministério da Saúde. Departamento de Atenção Básica. Secretaria de Atenção à Saúde. Estratégias para o cuidado da pessoa com doença crônica: diabetes mellitus. Cadernos de Atenção Básica, n. 36 [Internet]. Brasília: Ministério da Saúde; 2013 [cited 2015 Oct 02]. Available from: http://bvsms.saude.gov.br/bvs/publicacoes/estrategias_cuidado_pessoa_diabetes_mellitus_cab36.pdf

2. Sociedade Brasileira de Diabetes. Diretrizes da Sociedade Brasileira de Diabetes: 2014-2015. São Paulo: AC Farmacêutica; 2015. 
3. Majumdar A, Sahoo J, Roy G, Kamalanathan S. Improper sharp disposal practices among diabetes patients in home care settings: need for concern? Indian J Endocrinol Metab [Internet]. 2015 [cited 2016 Jan 12];19(3):420-5. Available from: http://www.ijem.in/ article. asp ; issn $=2230-8210 ;$ year $=2015 ;$ volume $=19 ;$ issue $=3 ;$ spage $=420 ;$ epage $=425 ;$ aulast $=$ Majumdar

4. Alves das Chagas I, Camilo J, dos Santos MA, Rodrigues FF, Arrelias CC, Teixeira CR, et al. Patients' knowledge of diabetes five years after the end of an educational program. Rev Esc Enferm USP [Internet]. 2013 [cited 2015 Oct 28];47(5):1137-42. Available from: http://www.scielo.br/pdf/reeusp/v47n5/0080-6234-reeusp-47-05-1137.pdf

5. American Diabetes Association. Diagnosis and classification of diabetes mellitus. Diabetes Care [Internet]. 2013 [cited 2015 Oct 10];36(1):S67-S74. Available from: http://care.diabetesjournals.org/content/36/Supplement_1/S67

6. Boas LCG, Lima MLSAP, Pace AM. Adherence to treatment for diabetes mellitus: validation of instruments for oral antidiabetics and insulin. Rev Latino-Am Enfermagem [Internet]. 2014 [cited 2015 Oct 22];22(1):11-8. Available from: http://www.scielo.br/pdf/ rlae/v22n1/0104-1169-rlae-22-01-00011.pdf

7. Alves SB, Souza ACS, Tipple AFV, Rezende KCD, Rezende FR, Rodrigues EG. Manejo de resíduos gerados na assistência domiciliar pela Estratégia de Saúde da Família. Rev Bras Enferm [Internet]. 2012 [cited 2015 Nov 27];65(1):128-34. Available from: http:// www.scielo.br/pdf/reben/v65n1/19.pdf

8. Brasil. Conselho Nacional do Meio Ambiente. Resoluções do CONAMA: Resoluções vigentes publicadas entre setembro de 1984 e janeiro de 2012. Brasília: Ministério do Meio Ambiente, 2012. Available from: http://www.mma.gov.br/port/conama/ processos/61AA3835/LivroConama.pdf

9. André SCS, Takayanagui AMM. Orientações sobre o descarte de resíduos gerados em domicílios de usuários de insulina. RBSP [Internet]. 2015 [cited 2016 Jun 10];39(1):105-18. Available from: http://inseer.ibict.br/rbsp/index.php/rbsp/article/viewFile/775/pdf_611

10. Brasil. Conselho Nacional de Saúde. Resolução n. 466/2012, de 12 de dezembro de 2012: aprova as diretrizes e normas regulamentadoras de pesquisa envolvendo seres humanos. Brasília, 2012. Available from: http://conselho.saude.gov.br/ resolucoes/2012/Reso466.pdf

11. Silva ARV, Zanetti ML, Forti AC, Freitas RWJF, Hissa MN, Damasceno MMC. Avaliação de duas intervenções educativas para a prevenção do diabetes mellitus tipo 2 em adolescentes. Texto Contexto Enferm [Internet]. 2011 [cited 2016 Jun 10];20(4):782-7. Available from: http://www.scielo.br/pdf/tce/v20n4/18.pdf

12. Serván PR. Obesity and diabetes. Nutr Hosp [Internet]. 2013 [cited 2016 Jun 8];28(5):138-43. Available from: http://www. nutricionhospitalaria.com/pdf/6929.pdf

13. Albuquerque $A B B$, Bosi MLM. Visita domiciliar no âmbito da estratégia saúde da família: percepções de usuários no município de Fortaleza, Ceará, Brasil. Cad Saúde Pública [Internet]. 2009 [cited 2015 Dec 29];25(5):1103-12. Available from: http://www. scielo.br/pdf/csp/v25n5/17.pdf

14. Sociedade Brasileira de Hipertensão. VI Diretrizes Brasileiras de Hipertensão. Arq Bras Cardiol [Internet]. 2010 [cited 2016 Feb 20];95:1-51. Available from: http://publicacoes.cardiol.br/consenso/2010/Diretriz_hipertensao_associados.pdf

15. Sampaio HAC, Carioca AAF, Sabry MOD, Santos PM, Coelho MAM, Passamai MPB. Letramento em saúde de diabéticos tipo 2: fatores associados e controle glicêmico. Cienc Saúde Colet [Internet]. 2015 [cited 2016 Jun 15];20(3):865-74. Available from: http://www.scielo.br/pdf/csc/v20n3/1413-8123-csc-20-03-00865.pdf

16. Gubitosi-Klug RA, Sun W, Cleary PA, Braffett BH, Aiello LP, Das A, et al. Effects of prior intensive insulin therapy and risk factors on patient-reported visual function outcomes in the diabetes control and complications trial/epidemiology of diabetes interventions and complications (DCCT/EDIC) cohort. JAMA Ophthalmol [Internet]. 2016 [cited 2016 Jun 9];134(2):137-45. Available from: http://archopht.jamanetwork.com/article.aspx?articleid $=2471237$

17. Ena J, Gómez-Huelgas R, Sánchez-Fuentes D, Camafort-Babkowsk M, Formiga F, Michán-Doña A, et al. Management of patients with type 2 diabetes and multiple chronic conditions: A Delphi consensus of the Spanish Society of Internal Medicine. Eur J Intern Med [Internet]. 2016 [cited 2016 Jun 9];27:31-6. Available from: http://www.ejinme.com/article/S0953-6205(15)00344-1/pdf

18. Gold K. Analysis: the impact of needle, syringe and lancet disposal in the community. J Diabetes Sci Technol [Internet]. 2011 [cited 2015 Dec 28];5(4):848-50. Available from: http://dst.sagepub.com/content/5/4/848.full.pdf + html

19. Ishtiaq O, Qadri AM, Mehar S, Gondal GM, Igbal T, Ali S, et al. Disposal of syringes, needles, and lancets used by diabetic patients in Pakistan. J Infect Public Health [Internet]. 2012 [cited 2015 Dec 20];5(2):182-8. Available from: http://www.jiph.org/article/S1876-0341(12)00026-3/pdf

20. Govender D, Ross A. Sharps disposal practices among diabetic patients using insulin. S Afr Med] [Internet]. 2012 [cited 2015 Dec 10];102(3):1634. Available from: https://www.researchgate.net/publication/221879658_Sharps_disposal_practices_among_diabetic_patients_using_insulin 